\title{
The Role of Methane and Methane Hydrates in the Evolution of Global Climate
}

\author{
Sarah Kh. Lifshits ${ }^{1 *}$, Vladimir B. Spektor ${ }^{2}$, Boris M. Kershengolts ${ }^{3}$, Valentin V. Spektor ${ }^{2}$ \\ ${ }^{1}$ Siberian Branch of Russian Academy of Sciences, Institute of Oil and Gas Problems, Yakutsk, Russia \\ ${ }^{2}$ Siberian Branch of Russian Academy of Sciences, Melnikov Permafrost Institute, Yakutsk, Russia \\ ${ }^{3}$ Siberian Branch of Russian Academy of Sciences, Institute for Biological Problems of Cryolithozone, Yakutsk, Russia \\ Email: *lifsara@yandex.ru
}

How to cite this paper: Lifshits, S.Kh., Spektor, V.B., Kershengolts, B.M. and Spektor, V.V. (2018) The Role of Methane and Methane Hydrates in the Evolution of Global Climate. American Journal of Climate Change, 7, 236-252.

https://doi.org/10.4236/ajcc.2018.72016

Received: January 12, 2018

Accepted: June 5, 2018

Published: June 8, 2018

Copyright $\odot 2018$ by authors and Scientific Research Publishing Inc. This work is licensed under the Creative Commons Attribution International License (CC BY 4.0).

http://creativecommons.org/licenses/by/4.0/

\begin{abstract}
For the first time, functioning of the planetary climate system is considered in terms of the self-organization laws with account of positive and negative feedbacks. It is shown that the maximum risks in the development of positive feedbacks that can lead the climate system to a planetary catastrophe, are associated with an unprecedented increase in the concentration of methane in the atmosphere. Over the last 30 years, its concentration in the atmosphere has increased by 2.5 times and continues to grow exponentially. In this review, we show that today the principal source for increase of methane concentration in the atmosphere is the self-accelerating decomposition of methane hydrates in the cryosphere of the Northern Hemisphere. In the history of the Earth, the emissions of methane into the atmosphere due to mass decomposition of methane hydrates led to climate-induced biosphere catastrophes. Paleo-reconstruction analysis of greenhouse gas concentrations in the atmosphere and its temperature over the last 420,000 years has allowed us to conclude that the self-organizing planetary climate system is currently in a state of dynamic chaos (close to the bifurcation point). This means that even a relatively weak impact on it, also of anthropogenic characters, is able to affect the planetary climate system to select its future development trajectory.
\end{abstract}

\section{Keywords}

Greenhouse Effect, Decomposition of Methane Hydrates, Permafrost, Biosphere Catastrophe, Self-Regulation in the Global Climate System

\section{Introduction}

One of the most important and most debated problems of the XXI century is the climate change, which is mainly associated with increase in greenhouse gas con- 
centrations in the atmosphere. Methane is one of the three natural compounds (water, carbon dioxide, methane) that define the greenhouse effect of the Earth's atmosphere and related climatic changes. Contributing to the greenhouse effect, water vapor is in the first place (36\% - 72\%), followed by carbon dioxide (9\% $26 \%$ ), and methane in the third place (4\% - 9\%) [1]. Until recently, methane along with ozone, nitrous oxide and other gaseous components were considered as greenhouse gases in the atmosphere, whose influence can be neglected. However, over the last 150 years, methane concentration in the atmosphere has increased drastically, according to the different estimates, from 2 [2] [3] to 3.5 times [4]. Especially the increase by 2.5 times-from 700 to $1800 \mathrm{ppbv}$ over the last 30 years is important to mention [3]. The increase of methane concentrations over the past millennium is plotted in Figure 1 [5], concluding that in the next 50 - 60 years the doubling of the concentration of $\mathrm{CH}_{4}$ is expected. As can be seen, the dependence is exponential.

Currently, the concentration of $\mathrm{CO}_{2}$ in the atmosphere is much higher than that of $\mathrm{CH}_{4}$ (360 ppmv and $1720 \mathrm{ppbv}$, respectively). The lifespan of carbon dioxide in the atmosphere is about 10 times higher than that of methane [3]. $\mathrm{CO}_{2}$ is the main component of industrial emissions and combustion products. As a result, the reasoning that carbon dioxide is the main factor in global climate change is riddled with. At the same time, it should be noted that carbon dioxide is characterized by different mechanisms of sink from the atmosphere, the main of which are: dissolution in water (the sea and oceans) and absorption vegetation. In contrast to $\mathrm{CO}_{2}$, methane is very slightly soluble in water and its main sink in the atmosphere is carried out chemically, namely, by interaction with the OH radical [6] [7] [8] [9]. The process of chemical methane sink occurs in multiple stages. An intermediate product of interaction is formaldehyde, which in turn triggers new cycles [7]. The stable products of the multi-step conversion cycle are $\mathrm{CO}_{2}, \mathrm{H}_{2} \mathrm{O}, \mathrm{O}_{3}$. Those, during the transformation of methane, form new

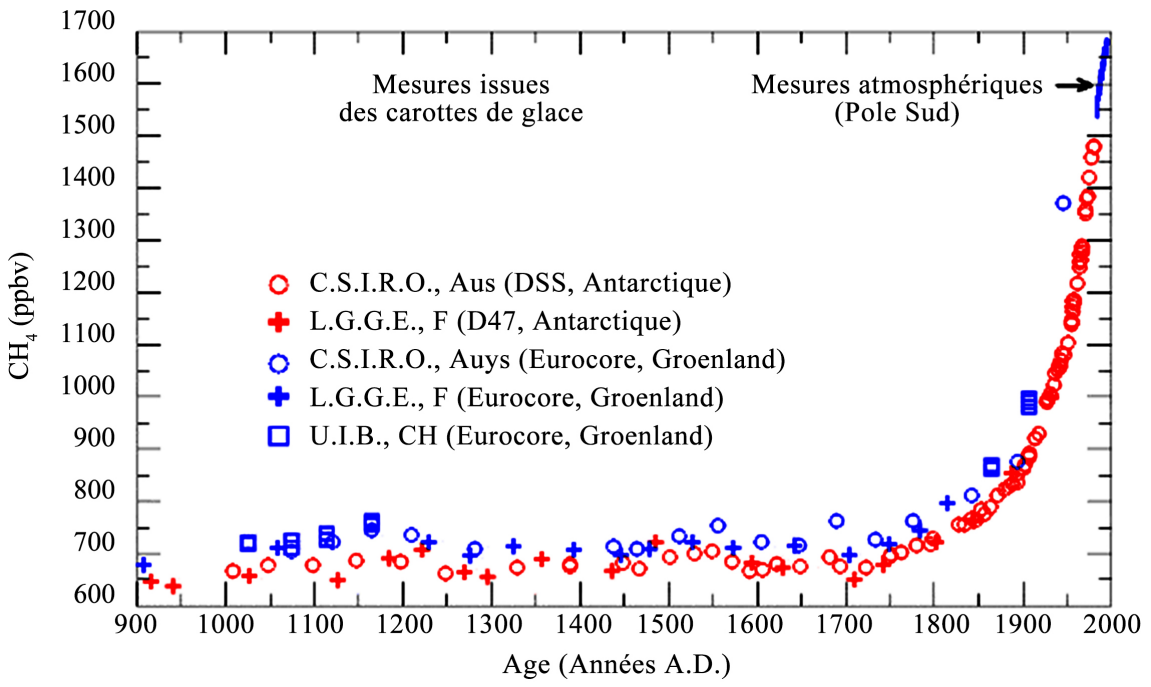

Figure 1. Change of the atmospheric methane content from 900 to 2000 A.D. [5]. 
gaseous compounds, which also create a greenhouse effect. As a result, the sink of $\mathrm{CH}_{4}$ in the atmosphere does not lead to the complete disappearance of the greenhouse effect caused by this gas. Gaseous intermediate and final reaction products will contribute their share of the greenhouse effect to the atmosphere. In addition, the lifespan of methane in the atmosphere depends on its concentration. With increasing concentration, the lifespan [7] [9] also increases, which is due to the chemical way of methane sink in the atmosphere. In the pre-industrial era, it used to be 8.4 years, but in modern conditions, 10 - 12 years [7] [9].

By the end of the 20th century $\mathrm{CH}_{4}$ contribution to the greenhouse effect has already reached $27 \%$ relative to the contribution of $\mathrm{CO}_{2}$ [10]. Those are the minimum estimates of the $\mathrm{CH}_{4}$ contribution to climate change as its radiation activity is 25 - 30 times higher than that of $\mathrm{CO}_{2}$, while the increase in the concentration is $2-4$ times higher [4]. It is stated that the climate role of $\mathrm{CH}_{4}$ was underestimated by approximately $20 \%-40 \%$. It should also be noted that only methane has a potential source in the form of methane hydrates, through which the concentration of this gas in the atmosphere can increase significantly. Connected to the growing role of methane in the climate system, it appears necessary to refine the balance of its mass in the atmosphere and the spatial position of its major sources.

\section{Sources of Methane Emission}

Currently, quantitative and genetic estimates of methane sources on the planet are largely undefined. According to [3], the mass of $\mathrm{CH}_{4}$ in the atmosphere is increasing at a rate of 20 million tons/year, and its contribution to the atmosphere is 5200 million tons. The flux of $\mathrm{CH}_{4}$ into the atmosphere is estimated to be $\approx 650$ - 600 million tons [3] [10] [11] [12] [13]. In recent years, due to the inability to cover the whole spectrum of $\mathrm{CH}_{4}$-sources, its global flux is established from the condition to maintain a balance, determined by the influx of $\mathrm{CH}_{4}$ from the lithosphere and the ocean, sink in the atmosphere and the observed spatial and temporal changes in mass. Since methane is not able to form in the Earth's atmosphere, its global flux is made up by the sum of the rate of mass change in the atmosphere and sink in it [3].

\subsection{Cryolithozone of the Northern Hemisphere-A Regulator of Methane Emission}

The main feature of the global $\mathrm{CH}_{4}$ flux is the establishment of different flow modes in the Northern (NH) and Southern (SH) hemispheres [3] [14] [15]. In the $\mathrm{SH}$, the concentrations of $\mathrm{CH}_{4}$ do not depend on latitude and are determined only by seasonal variations. In the $\mathrm{NH}$, a noticeable increase in methane concentration with increasing latitude can be observed and its variations do not match the seasonal variation of solar radiation [3] [14]. In the continental part of higher latitudes in the $\mathrm{NH}, \mathrm{CH}_{4}$ concentration increases dramatically in autumn 
(August-September) and continues to increase until December. It is obvious that the increase in mass of methane at this time of the year in the $\mathrm{NH}$ atmosphere "is related to the entry into force of the sources of the Arctic region" [3]. Recalculations carried out by the authors and based on the maintenance of balance of methane in the atmosphere, resulted in following: sink and influx of methane in the $\mathrm{SH}$ amount is approximately 470 million tons/year with seasonal fluctuations of 36 million tons/month in June-July, and 43 million tons/month in December-January. The methane sink in the NH is about 510 million tons/year, its income is 530 million tons/year, with seasonal fluctuations of 25 million tons/month in December-January and 70 million tons/month in August-September, i.e. the increment of its content is about 20 million tons/year (Figure 2).

As the concentration of $\mathrm{CH}_{4}$ grows in the $\mathrm{NH}$ with increasing latitude, it can be assumed that its debits growth is related to the temperature regime in the permafrost zone. Apparently, the influx of $\mathrm{CH}_{4}$ to upper horizons of permafrost is ensured by its migration from deeper horizons of sedimentary cover, in which reserves of hydrocarbons are concentrated. In permafrost conditions, the gas is conserved in the form of gas hydrates.

Moreover, relict methane hydrates may be found in permafrost. Their formation near the surface of the ground appear to have occurred due to decomposition of organic material in water-saturated rocks under certain thermobaric conditions, created by the action of an external load, such as an overlying ice sheet [16]. When permafrost thaws, gas hydrates begin decomposing and the fluid migrates into the atmosphere. It is in August to September when permafrost thawing reaches a maximum in coastal areas of the NH. According to [17], the following dynamic of increasing the depth of the seasonally thaw layer in tundra soils could be observed: $45 \%$ - $50 \%$ of it thaws by the beginning of July, $80 \%-90 \%$ by early August, and $100 \%$ by September (Figure 3 ). The completion of seasonal thawing by September occurs in most of the taiga permafrost zone of North Asia [18] [19] [20] [21].

At the same time, in August and September the temperature of the bottom water layers in thermokarst lakes reaches a maximum. In lakes with a depth of 1 - $2 \mathrm{~m}$ the temperature is quickly established throughout the depth, reaching $20^{\circ} \mathrm{C}$ in the taiga zone. In deeper lakes $(6-8 \mathrm{~m})$ the temperature at the bottom reaches $+4^{\circ} \mathrm{C}$ to $+5^{\circ} \mathrm{C}$ in the tundra zone, and $+10^{\circ} \mathrm{C}$ in the taiga zone [22]. High temperatures at near-bottom layers of water cause disruptions of the upper permafrost horizons, up to forming sublake taliks [23] [24] [25].

Gas hydrates are able to be in a state of self-preservation [26], which is due to the formation of an ice cover on the surface of hydrate particles as a result of the endothermic decomposition of methane hydrates, which prevents their free release of gas [27]. Violations of the metastable state may occur as a result of a $0.5^{\circ} \mathrm{C}-1^{\circ} \mathrm{C}$ increase in permafrost temperatures and reduce of external pressures of $0.1-0.2$ atmosphere. Such conditions are reached by increasing the surface temperature of the air in the Arctic in the past 30 - 50 years. 


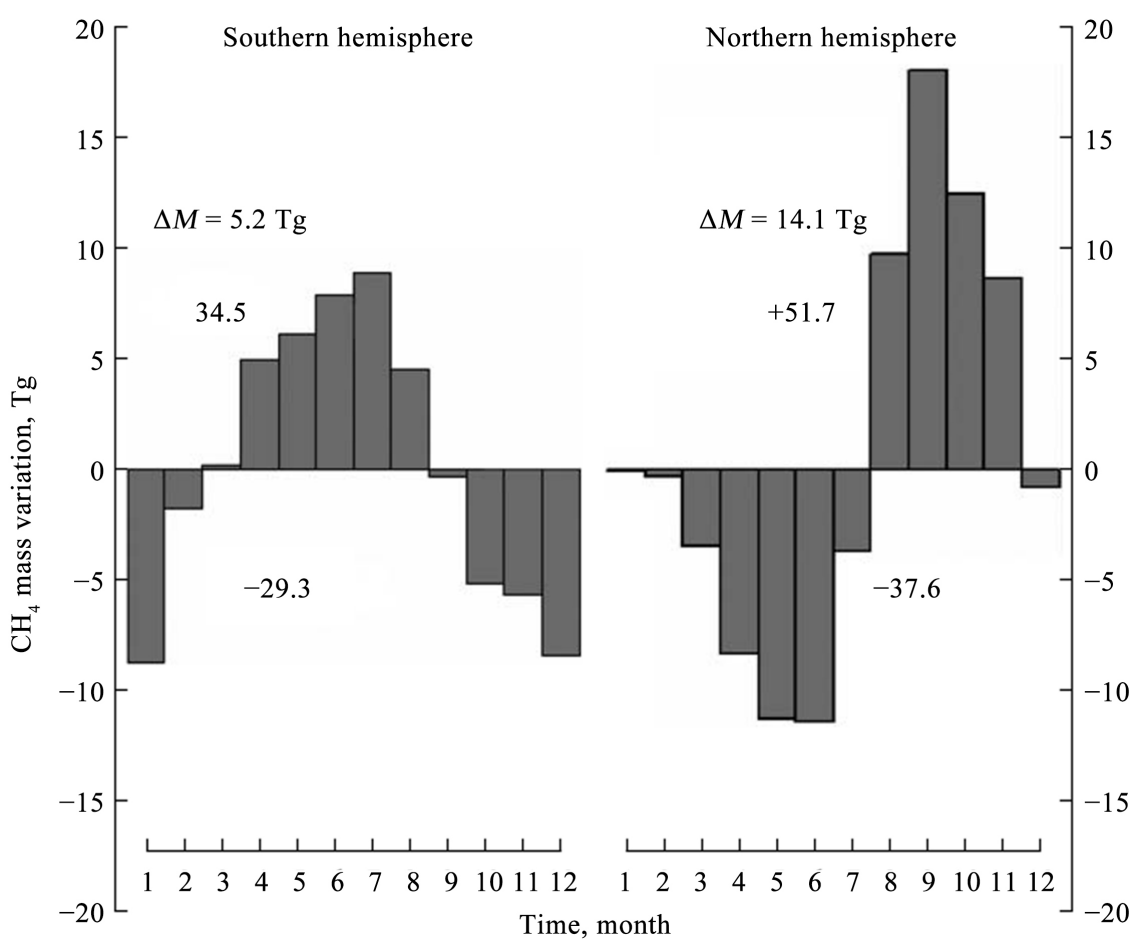

Figure 2. Seasonal dependence of the variation rate of the methane mass in the atmosphere of the Southern and Northern Hemispheres in 1996 [3].

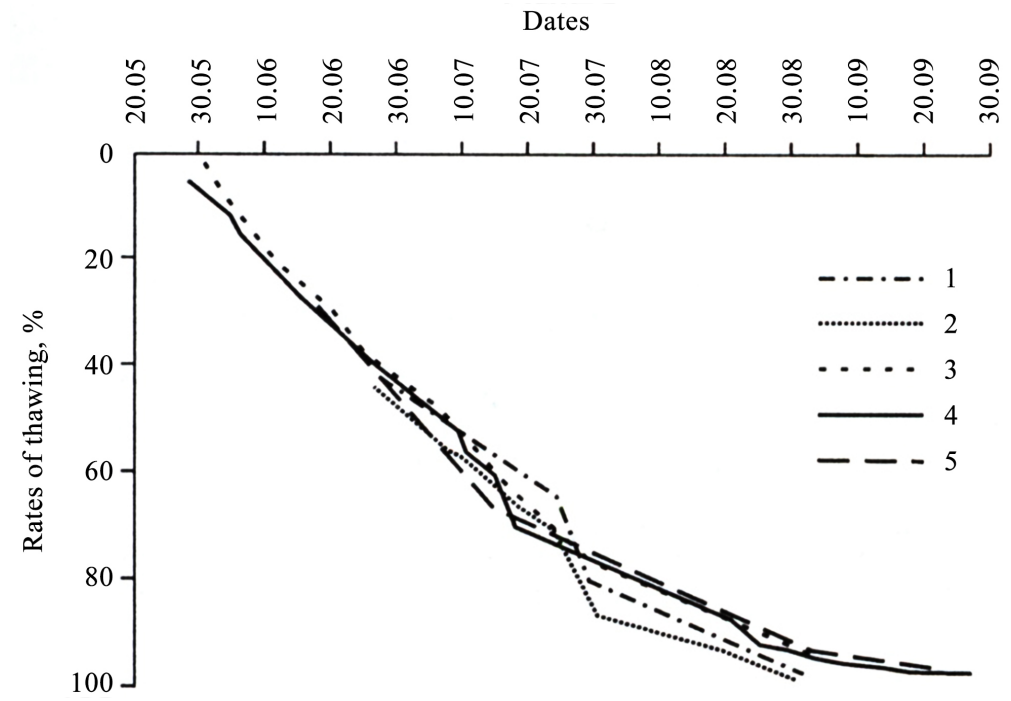

Figure 3. The average rate of seasonal thawing tundra soils in the area of the lake Achmelo (the lower stream of the Kolyma river) [17]. 1-according to the 1989 defined in multiple replications; 2-according to the 1989 defined in a single repetition; 3-according to the 1990 defined in multiple replications; 4-according to 1990, defined in a single repetition; 5-according to 1991 identified in multiple replicates.

According to [28] in the Arctic $\left(60-85^{\circ} \mathrm{N}\right)$ the increase in constant deviation in the mean annual temperature has reached $+2^{\circ} \mathrm{C}$ since 1980 , while in the Northern Hemisphere $\left(0-90^{\circ} \mathrm{N}\right)$ it was only $+0.7^{\circ} \mathrm{C}$. According to [29], the sur- 
face air temperature in the Arctic regions of Russia changes at a rate of $0.6^{\circ} \mathrm{C}$ $0.9^{\circ} \mathrm{C}$ /year. The increases of permafrost temperatures are approximately 1.5 times less than those of air temperatures on the earth's surface [29]. I.e. the permafrost temperature can only increase in around $0.4^{\circ} \mathrm{C}$ a year. The uplift of the Arctic plains territory [30], associated with glacioisostatic movements [31], can contribute to the decrease in hydrostatic pressure and increase in permeability in permafrost.

Gas bubbles of $\mathrm{CH}_{4}$ are often observed on the surface of lakes in tundra zones [32] [33]. Its emissions are also encountered in boreholes when drilling in the base of the annual temperature variations layer in the tundra and taiga zones. The isotopic analysis of the gas bubbles from the tundra zone showed that $\mathrm{CH} 4$ from tundra lakes has a more "heavy" isotopic composition than the typical biogenic methane (marsh gas), for which applies: $\delta^{13} \mathrm{C}=-66 \div-100 \%$ [ [3]. According to [32] [33] [34], $\mathrm{CH}_{4}$ can be formed due to decompositions of organic matter from cryogenic sediments of the Arctic plains. The highest methane flux is observed during the maximum seasonal thawing of permafrost, rather than in the period of maximum air temperatures during summer. This also indicates the deep-seated origin of methane.

According to [32] the lakes of Northern Siberia deliver 3.8 million tons of methane/year into the atmosphere and the estimated emission from Northern wetlands of $<6-40$ million tons/year should be increased by $10 \%-63 \%$. In this way, the share of Northern wetlands should account for about $10 \%$ of methane emission in the NH.

Numerical modeling carried out by [8] using the global chemical and climatic model of the lower and middle atmosphere showed that the contribution of methane emissions from Arctic gas hydrates to global emissions is currently underestimated.

\subsection{Shallow Shelf of the Northern Hemisphere-A Main Source of Methane Emission}

The shallow shelves of the Arctic seas, particularly the seas of the Eastern Arctic (the Laptev, East Siberian and Chukchi sea), are the most extensive shelfs of the World Oceans: they hold a significant portion of the shallow gas hydrates (GH) and $80 \%$ of the submarine permafrost [35] [36]. It is also regarded as the main supplier of methane in the $\mathrm{NH}$ [8] [37]. In the arctic region (north of $66^{\circ} \mathrm{N}$ ), methane flows from gas hydrates make up about $50 \%$ of the total flow, and north of $75^{\circ} \mathrm{N}$, the flow of methane from gas hydrates is the only source [8].

In relation to the submarine permafrost there are two points of view. The first and most common, is based on the concept of the substantial thickness of permafrost, its low temperatures, gas isolating properties, and stable state of GH in it [35] [38] [39]. Its supporters come from the fact that the change in the isolating properties of submarine permafrost is determined only by climatic changes. According to them, a modern shallow shelf of the Eastern Arctic seas is composed of Ice Complex - a stratum of silty sediments with ice wedges. In this case, 
the permafrost thickness would be several hundred meters. They believe that by the end of the year 3000 the thickness of the upper layer of thawed sediments will be $90 \mathrm{~m}$ and is not going to reach the threshold of the zone of GH distribution, which is at a level of $100-140 \mathrm{~m}$ under the bottom shelf, so that the «methane catastrophe» on the shelf seas of the Eastern Arctic will be not possible [35] [40]. This point of view does not explain the widely ubiquity of methane outputs in the shallow shelf, its high constant influx and the presence of areas on this territory with a small thickness and high temperatures of permafrost.

An alternative viewpoint is that, in addition to climate, there are many other factors destabilizing submarine permafrost. These are physical factors as the salinization of underwater soil and unfrozen water, taliks, degassing processes on various types of channels and the destruction of the storages of gas hydrates, etc. [37] [41]. Author of another research papers [40] [42], supports the point of view of the stable state subaquatic permafrost nonetheless considers it necessary to take into account the destabilizing factor in a possible development of thermokarst lakes and the formation of submarine taliks. "Talik formation below paleo-river channels creates permeable pathways for gas migration from depth" [41]. According to [41] that "sustained submergence into the future should increase gas venting rate roughly exponentially as sediments continue to warm". In our opinion, all these factors are of importance for the degradation of permafrost, but do not explain the "methane explosion" occurring in the Holocene. The decisive condition cardinally changed the permeability of the permafrost zone, which apparently is the glacioisostatic rise of the modern shelf and adjacent land, resulting in horizontal stretching of the upper permafrost horizons, and therefore tension cracks [30] [31]. According to this theory, a large part of the shallow shelf of the Eastern Arctic in the Late Pleistocene was probably covered with ice sheet, not allowing an Ice Complex to be formed here [31] [43] [44].

Temperatures of permafrost under the ice sheet were most certainly not high and did not differ heavily from the current. Modern submarine permafrost has a complex discontinuous or even sporadic distribution with a temperature of not more than $-2^{\circ} \mathrm{C}$ [31] [45] [46] [47]. Despite an infrequent observation network, areas with a thin submarine permafrost have been established. For instance, in the Dmitry Laptev Strait, the thickness of submarine permafrost exposed by drilling varied from 2 to $20 \mathrm{~m}$ [37]. I.e. the thickness of permafrost on the shelf seas of the Eastern Arctic can apparently not constitute an insurmountable obstacle to the emission of gas into the atmosphere.

The shelf at the Eastern Arctic has an abnormally high methane concentration in the water [4] [37], a high background flow of $\mathrm{CH}_{4}$ and local sources with a high output of gas [35]. The average $\mathrm{CH}_{4}$ emission is $3 \mathrm{mg} / \mathrm{m}^{2 *}$ day, although from its localized plumes on the shelf it is $13 \mathrm{mg} / \mathrm{m}^{2 *}$ day [35]. During the ice-free period, local sources of methane on the East-Arctic shelf put up to 13.7 $\times 10^{4} \mathrm{~g} \cdot \mathrm{km}^{-2} \mathrm{CH}_{4} /$ year [37]. High concentrations of methane in the water and over water air layers indicate significant permeability of submarine permafrost 
in the Arctic seas. Surface waters in half of the studied water areas were extremely saturated with methane at an average of 8.8 times. Areas in which the concentration of dissolved $\mathrm{CH} 4$ was extremely high, exceeding the average of 80 to 1400 times, were observed. The flow of gas bubbles that were most likely associated with the destruction of GH were detected [37]. Numerous observations suggest that GH may be located even at the surface of the seabed, if the content of hydrate-forming gas exceeds the limit of its solubility in water. To maintain such a high gas concentration in case of GH formation, the existence of a constant inflow of $\mathrm{CH}_{4}$ to the bottom surface is required [48]. Perhaps, in this case, the formation of dissipative gas hydrate structures in the sink of deep fluid outputs takes place.

It is quite possible, that at the seabed of the Eastern Arctic similar GH can be found, which is in an unstable state and might break down with even small interventions in the environment. So in the Laptev Sea near the Lena River delta the emissions of gas from sediment sources were observed, caused just by the working marine engine [49]. In some cases emissions raised to $0.7-2.1 \mathrm{~g}$ $\mathrm{CH}_{4} / \mathrm{sec}$, which is comparable to the capacity of deep-sea mud volcanoes. Obtained using satellite data [50] of methane concentrations over the Okhotsk Sea during the autumn-winter season 2015-2016, indicating the detection of anomalies of atmospheric methane, which reaches $70-100 \mathrm{ppb}$, compared to previous years. Methane abnormality along the north-western coast of the Okhotsk Sea can presumably be explained by the release of methane into the atmosphere as a result of degradation of the natural subaquatic permafrost, similar to processes occurring in the Laptev Sea. In [51] it is noted that in the coastal zone of the Laptev and East-Siberian seas there are noticeable changes in the cryogenic complex (permafrost rocks, ice seashores) caused by the degradation of the roof of subaquatic permafrost. It is also noted that the intensification of destruction rates of thermoabrasion shores occurred in the period from 2000 to 2009.

According to its isotopic composition, the gas dissolved in the sea water is thermogenic ( $\delta^{13} \mathrm{C}$-from $50.9 \%$ o to $63.4 \%$ ond $\mathrm{D}$-from $47.5 \%$ o to $65.8 \%$ ) and gas hydrate (13C-from $63 \%$ o to $58 \%$ ond $\delta \mathrm{D}$-from $176 \%$ o to $196 \%$ ) [37]. It is heavier than the gas in the tundra lakes. This also points to a higher permeability of submarine permafrost than permafrost of the Siberian coastal plains. Methane from shallow shelf of high-latitude seas is most likely epigenetic [37] [52] and its emission is provided by the influx of gas from the depths. The total emission of methane from the shallow shelf of the Eastern Arctic seas is at least 8 million tons/year, but a more recent estimation considering the bubble migration is 17 million tons/year [37]. The flux of methane from the bottom of the shallow shelf is also observed in the North-American sector (Beaufort Sea) of the Arctic ocean shelf [41] [53]. "An estimate of the maximum gas flux at the present time for conditions at the East Siberian Arctic Seas is $0.2047 \mathrm{~kg} \mathrm{yr}^{-1} \mathrm{~m}^{-2}$, which produces a methane concentration of $142 \mathrm{nM}$ in the overlying water column, consistent with several field observations. For conditions at the North American Beaufort 
Sea, the maximum gas flux at the present time is $0.1885 \mathrm{~kg} \mathrm{yr}^{-1} \mathrm{~m}^{-2}$, which produces a methane concentration of $78 \mathrm{nM}$ in the overlying water column" [41]. According to [54], the decomposition of GH at the shelfs of the World oceans delivers today's methane at least as much as all its sources on land. As can be seen from the examples above, submarine permafrost is sufficiently permeable to fluids, and their emission into the atmosphere appears to be controlled by the state of the permafrost zone.

The total carbon stock in GH is estimated to be at $1.0-1.2 \times 10^{4} \mathrm{Gt}$. In comparison, about $0.8 \times 10^{4} \mathrm{Gt}$ of carbon is dissolved in the ocean, $\approx 0.2 \times 10^{4} \mathrm{Gt}$ is in the soil and plants, $\approx 0.073 \times 10^{4} \mathrm{Gt}$ in the atmosphere, and $\approx 0.5 \times 10^{4} \mathrm{Gt}$ are the total reserves of fossil fuel, including coal [13]. The currently available simplified evaluation of changes in temperature profiles of the Earth's crust [55] allows us to conclude that submarine $\mathrm{GH}$, located in the waters of the World's oceans, inland seas and lakes, may not be a source of concern yet. With any change they will remain stable in the next thousands of years. The greatest danger is $\mathrm{GH}$, which is now already in a metastable state in permafrost and at the bottom of the Arctic Ocean. Particularly vulnerable to climate change are GH sediments of the Arctic continental shelves. According to the data above, the minimum emission of methane in the $\mathrm{NH}$ can be estimated as following: Northern plains-6 - 40 million tons/year, lakes of the Northern plains $-\approx 4$ million tons/year, shallow shelfs of all waters in the Arctic Ocean-8 - 20 million tons/year. That significantly covers the excess emissions of the NH (20 million tons/year) and considerably affects the rate of global warming [56]. According to [14] additional streams of methane in the $\mathrm{NH}$ are estimated to exceed 150 million tons/year, including the contribution in shallow-water of the Arctic shelf at 90 million tons/year, emissions from thermokarst lakes in Eastern Siberia and Alaska at 24 million tons/year, and geological sources of 35 million tons/year.

\subsection{Role of Global Climatic Warming in the Increased Methane Emission}

The relationship between methane emissions and climate warming is not random. Especially in the North-East of Asia, in the coldest region of the $\mathrm{NH}$, the average annual temperatures grew at a trend of $0.06^{\circ} \mathrm{C}$ to $0.09^{\circ} \mathrm{C} /$ year over the last 50 years [57]. And especially there, there is an increase in methane emission rates, whose concentration was at least doubled in the past $40-60$ years (see Figure 1). This can lead to an abrupt rise in temperature of $1^{\circ} \mathrm{C}-1.3^{\circ} \mathrm{C}$ in the near future (in about 30 years), and $3.3^{\circ} \mathrm{C}$ by the end of this century [37]. Such high rates of temperature increase can be explained by positive feedbacks in the climate system, which includes the growth of temperature in lower atmosphere layers and the earth's surface, causing an increase in greenhouse gas emissions, followed by further warming of the atmosphere and underlying surfaces. In addition, this increase is already beginning to trigger other processes in the Arctic as the reduction of the ice cover, a longer duration of the ice-free period [37], 
enhanced wind activity and the destruction of coasts, sea transgression, and the degradation of permafrost.

It is possible that formation of the famous funnels in the Yamal Peninsula in 2014-2016 that occurred explosively, as well as formations of various small round lakes, were due to the decomposition of GH in cryolithozone [16]. The first discovered funnel has a depth of approximately $200 \mathrm{~m}$ (upper diameter 60 $\mathrm{m}$, lower $40 \mathrm{~m}$ ) and it is the upper limit of GH occurrence in the cryosphere [13] [58]. A significant risk is posed by the potential proximity of the formed funnels to animal burial sites and graves of people who died from highly dangerous infections in the XVIII-XX centuries and were buried in the upper layer of the permafrost since the formation of the funnels is accompanied by powerful explosions due to high pressure of gas accumulating under the overlying frozen ground. With the blast of the explosion, the spores of bacteria can spread to tens and hundreds of meters. For example, the scattering of soils at funnel formation on the Yamal Peninsula was as much as $120 \mathrm{~m}$. It is not excluded that outbreak of anthrax on the Yamal Peninsula in summer 2016 was not only due to favorable weather conditions (hot July), but the decomposition of GH in thawing permafrost. The increase of temperature on the Earth's surface by $3^{\circ} \mathrm{C}$ can lead to destabilization of $\approx 85 \%$ of the existing deposits of oceanic $\mathrm{GH}$, which will result in the release of $(4 \div 8) \times 10^{3} \mathrm{Gt}$ of carbon, while its amount (in form of methane and carbon dioxide) in the modern atmosphere is only $730-760 \mathrm{Gt}$ [13] [37].

Authors [59] give the reasons for the urgency of adaptation to the current and expected impacts of climate change in the Arctic with some variation in order to reduce the populations and economics entities vulnerable to these changes. [60] discussed the problems associated with the emission of methane into the atmosphere in the Arctic region and climate warming.

\section{3. "Methane Catastrophe" as a Result of a Critical State of the Planetary Climate System}

\subsection{Increase in Methane Emission due to Operation of Self-Regulating Climatic System}

The Planetary climate system is an open thermodynamic, strongly non-equilibrium and non-linear, i.e. self-regulating dissipative system [61]. Current climate warming with an interval from 0 to $12 \mathrm{kyr}$ (Figure 4) is one of several very similar temperature peaks of the last $450 \mathrm{kyr}$. The last closest to the current maximum was reached about 117 - 127 kyr. During these peaks, also in the present, the temperature of the surface air layers and the emission of greenhouse gases dramatically increases, glaciers are receding, and wind and humidity conditions change abruptly. Particularly important is the inflection point on the temperature curve, which is where the temperature growth in the atmosphere and earth's surface is sharply decreasing (see Figure 4). In this state of the climate system (called "dynamic chaos"), a bifurcation point is approached due to 


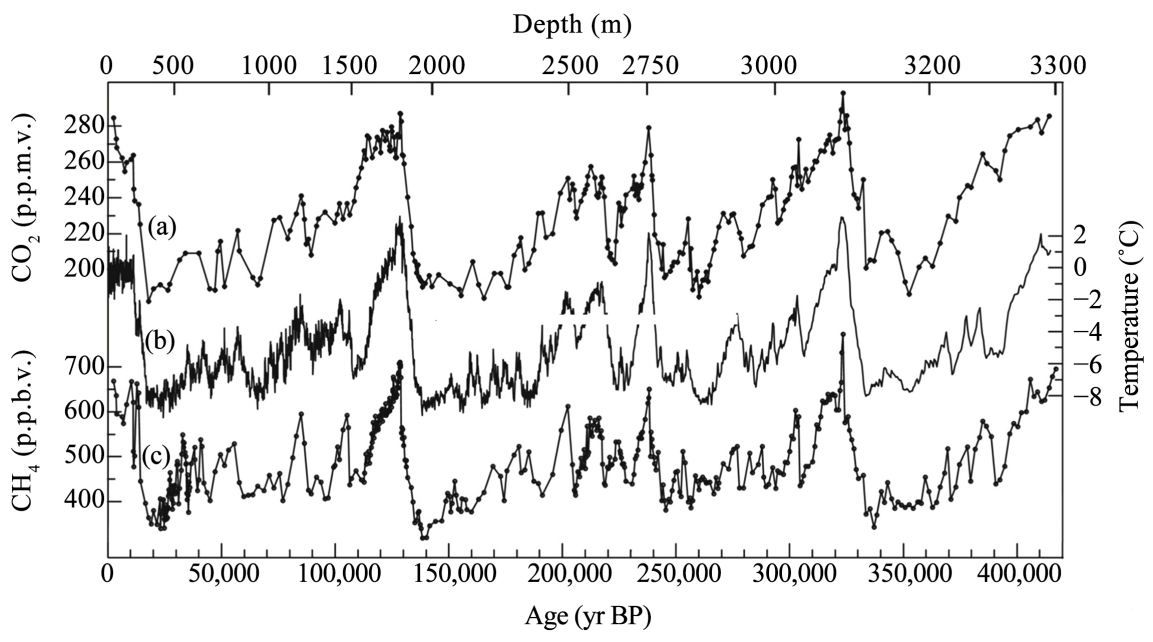

Figure 4. Changes in the concentrations of $\mathrm{CO}_{2}$ (a) and $\mathrm{CH}_{4}$ (c) in the atmosphere and air temperature (b) in Antarctica over the last 420 thousand years [62].

very weak fluctuations, a system selects the further way of evolution: the decrease or the continuing increase of temperature and emissions self-accelerating vectors. Currently, the climate system is in fact at a point of bifurcation. This can be proven by the increasing number of weather disasters.

For example, according to Roshydromet's statistics, the number of dangerous weather-related phenomena in Russia has almost doubled over the past 25 years [63]. After analyzing 50 different models describing climate changes the authors of [64] concluded that the more frequent happening of extreme weather phenomena in the world is related to the increase of greenhouse gases concentration in the atmosphere. They state that it is possible to trace the relationship between the human-induced global warming and the frequency of extreme weather events. The relationship between climate change and the emergence of natural disasters was proved by American scientists [65] who discovered traces of warming by the study of tropical cyclones in the Pacific, unusually high summer temperatures in Europe, China, South Korea and Argentina, as well as forest fires in California. Climate change has also catalyzed drought in Africa and the Middle East, snowstorms in Nepal and torrential downpours that have caused floods in Canada and New Zealand.

It should be noted that unlike the previous temperature maxima (117 - 127 kyr and others) the present-day extreme concentrations of greenhouse gases: $\mathrm{CO}_{2}$ and especially $\mathrm{CH}_{4}$, in the atmosphere are significantly $(30 \%$ and $145 \%$, correspondingly) higher, and continue to grow. At the bifurcation point, even a very weak change in control parameters or other variables influencing the climate system can cause a cumulative effect and due to the fact that positive feedbacks will not be replaced by negative feedbacks, it is likely to withdraw the system in the area of other patterns, until it loses the ability of self-regulation and self-organisation.

One possible option for the destruction of the functioning climate system is a dramatic warming «methane catastrophe», which leads to a loss of oxygen in the 
oceans and is followed by the destruction of the Earth's global ecosystem [9] [66]. A danger signal for the possibility of the «methane catastrophe» is the unprecedented growth of methane in the atmosphere (see Figure 1). This phenomenon has generated a series of hypotheses (i.e. "The Hypothesis of a methane climate catastrophe") which is stating that by increasing the oceans temperature (and/or fall of its level) $\mathrm{CH}_{4}$ can suddenly be released from sediments of $\mathrm{GH}$ under the seabed (or from permafrost). In the Earth's history, such catastrophic events had already taken place in Mesozoic and Cenozoic time, accompanied by global oceanic anoxic events [66]. Recent rapid warming (over several millennia) can be dated about 55 million years ago, between Paleocene and Eocene epochs (Paleocene-Eocene Thermal Maximum (PETM)). It is assumed that it was caused by the decomposition of almost all oceanic GH accumulated by that time (about $1200 \mathrm{Gt} ; \approx 1 / 10$ part of the modern stocks) [9] [13] [66].

\subsection{Anthropogenic Factor in the Increasing Methane Emission}

It is not excluded that human activities contribute their share to the development of the climate scenario at the present stage. Anthropogenic sources of $\mathrm{CH}_{4}$ (agricultural activities, losses of $\mathrm{CH}_{4}$ in the mining of fossil fuel and industrial emissions of methane) have, by various estimates, an annual average flow of 0.35 [7] to 1.1 [67] billion tons/year that corresponds to $18 \%$ to $58 \%$ of the capacity of its natural abundance. In this place the authors do not take into account the contribution of light hydrocarbons evaporating in numerous spills and leaks of oil and petroleum products in the process of production, transportation, storage and its processing. Oil industry is ranked third among 130 industries of modern production by hazardous impact on the environment. In addition to the direct impact on the balance of greenhouse gases, anthropogenic influence on the climate system includes deforestation, forest fires, pollution of water surfaces, primarily the Oceans, and destruction of permafrost.

Another work [68] describes a six year field observation in a shrub removal experiment at a Siberian tundra site. It is shown that "removing the shrub part of the vegetation only initiated thawing of ice-rich permafrost, resulting in the collapse of the originally elevated shrub patches into waterlogged depressions within five years. This thaw pond development shifted the plots from a methane sink into a methane source". During the experiment period "the permafrost table lowered on average by $31 \mathrm{~cm}$ in the removal plots". "This permafrost collapse occurred despite a mean annual temperature of $-13.4^{\circ} \mathrm{C}$ ". The results of this "field experiment demonstrate the importance of the vegetation cover for protection of the massive carbon reservoirs stored in the permafrost and illustrate the strong vulnerability of these tundra ecosystems to perturbations". The authors [69] note, that the release of greenhouse gases like $\mathrm{CO}_{2}$ and $\mathrm{CH}_{4}$ form a positive feedback to their atmospheric concentrations and accelerates climate change. 


\section{Conclusion}

Given the fact that the main cause for the increase in methane concentration in the atmosphere is currently observed in the high latitudes of $\mathrm{NH}$ and is determined by the temperature regime of the permafrost zone and also the fact that a climate catastrophe in Earth's history was associated with the unprecedented growth of methane concentration in the atmosphere, we should be very careful in the development of the Arctic zone as the main source of methane hydrates, of which a large amount is currently already in a metastable state. It follows from the foregoing that in the terms of a "climate crisis", which is currently happening with our planet, anthropogenic factors may contribute to irreversible consequences in the self-regulating climate system and the future trajectory of its development, resulting in increased responsibility of human beings for their activities.

\section{Funding}

This research did not receive any specific grant from funding agencies in the public, commercial, or not-for-profit sectors.

\section{References}

[1] Boldyrev, V.M. (2016) Water Vapor and "Greenhouse Effect". Information Agency Regnum, February 26, 2016. https://regnum.ru/news/innovatio/2086744.html

[2] Mikaloff Fletcher, S.E., Tans, P.P., Bruhwiler, J.B., Miller, J.B. and Heimann, M. (2004) $\mathrm{CH}_{4}$ Sources Estimated from Atmospheric Observations of $\mathrm{CH}_{4}$ and Its 13C/12C Isotopic Ratios: 1. Inverse Modeling of Source Processes. Global Biogeochemical Cycles, 18, 1-17.

[3] Adushkin, V.V. and Kudryavtsev, V.P. (2010) Global Methane Flux into the Atmosphere and Its Seasonal Variations. Izvestiya. Physics of the Solid Earth, 46, 350-357. https://doi.org/10.1134/S1069351310040075

[4] Shakhova, N.E. (2010) Methane in the Seas of the Eastern Arctic. Dr. Sci. Thesis, P.P. Shirshov Institute of Oceanology, Moscow.

[5] Temporal Evolution of Methane (CH4). (2011) http://lgge.osug.fr/article374.html?lang=fr

[6] Seinfeld, J.H. and Pandis, S.N. (1998) Atmospheric Chemistry and Physics: From Air Pollution to Climate Change. John Wiley and Sons, New Jersey.

[7] Bazhin, N.M. (2000) Methane in Atmosphere. Soros Educational Journal, Chemistry, 6, 52-57.

[8] Smyshlyaev, S.P., Blakitnaya, P.A., Mareev, E.A. and Galin, V.Y. (2015) Modeling the Influence of Methane Emissions from Arctic Gas Hydrates on Regional Variations in Composition of the Lower Atmosphere. Izvestiya Atmospheric and Oceanic Physics, 51, 412-422. https://doi.org/10.1134/S000143381504012X

[9] Golitsyn, G.S. and Ginzburg, A.S. (2007) Estimates of the Possibility of Rapid Methane Warming 55 Ma Ago. Doklady Earth Sciences, 413A, 487-490. https://doi.org/10.1134/S1028334X07030361

[10] Etiope, G. (2004) New Directions: GEM-Geologic Emission of Methane, the Missing Source in the Atmospheric Methane Budget. Atmospheric Environment, 
38, 3099-3100. https://doi.org/10.1016/j.atmosenv.2004.04.002

[11] Lowe, D.C. (2006) A Green Source of Surprise. Nature, 439, 148-149. https://doi.org/10.1038/439148a

[12] Adushkin, V.V., Kudryavtsev, V.P. and Turuntaev, S.B. (1998) Evaluate the Magnitude of the Abiogenic Component of the Flow of Methane into the Atmosphere. In: Dobretsov, N.L. and Kovalenko, V.I., Eds., Global Changes of Environment, SB RAS, SPC UIGGM, Novosibirsk, 191-205.

[13] Denisov, S.N., Arzhanov, M.M., Eliseev, A.V. and Mokhov, I.I. (2011) Assessment of the Response of Subaqueous Methane Hydrate Deposits to Possible Climate Change in the Twenty-First Century. Doklady Earth Sciences, 441, 1706-1709. https://doi.org/10.1134/S1028334X11120129

[14] Adushkin, V.V. and Kudryavtsev, V.P. (2013) Estimating the Global Flux of Methane into the Atmosphere and Its Seasonal Variations. Izvestiya: Atmospheric and Oceanic Physics, 49, 128-136. https://doi.org/10.1134/S0001433813020023

[15] Volodin, E.M. (2015) Influence of Methane Sources in Northern Hemisphere High Latitudes on the Interhemispheric Asymmetry of Its Atmospheric Concentration and Climate. Izvestiya: Atmospheric and Oceanic Physics, 51, 251-258. https://doi.org/10.1134/S0001433815030123

[16] Arzhanov, M.M., Mokhov, I.I. and Denisov, S.N. (2016) Destabilization of Relict Methane Hydrates with Observed Changes of Regional Climate. The Arctic: Ecology and Economy, 4, 48-51.

[17] Fyodorov-Davydov, D.G., Davydov, S.P., Davydova, A.I., Zimov, S.A., Mergelov, N.C., Ostroumov, V.E., Sorokovikov, V.A., Kholodov, A.L. and Mitroshin, I.A. (2004) Spatial and Temporal Regularities of Soil Seasonal Thawing in the North of the Kolyma Lowland. Earth Cryosphere, 8, 15-26.

[18] Garagulya, L.S., Kudryavtsev, V.A., Kondratieva, K.A. and Maksimova, L.N. (1970) Influence of Geological and Geographical Factors on the Temperature Regime of Rocks of the Seasonal Thaw Layer in the Northern Part of the Yana-Indigirka Interfluves. Merzlotnye Issledovaniya, X, Moscow State University, Moscow, 59-79.

[19] Kondratieva, K.A. and Trush, N.I. (1961) To the Question Concerning Determination of the Depths of Seasonal Freezing and Thawing of Soils. Merslotnye Issledovaniya, II, Moscow State University, Moscow, 59-70.

[20] Matveyeva, N.V. (1971) Dynamics of Thawing of the Active Layer in the Tundra of the Western Taimyr. In: Tichomirov, B.A., Ed., Biogeocenoses of Taimyr Tundra and Their Productivity, Publishing House "Nauka", Leningrad, 45-56.

[21] Bogatyrev, L.G. (1974) Dynamics of Thawing Permafrost in the Tundra Soil Field Base “Agape Feast”. In: Kovda, V.A., Ed., Soil and Productivity of Plant Communities, Moscow State University, Moscow, 67-73.

[22] Pavlov, A.V. (1999) The Thermal Regime of Lakes in Northern Plain Regions. Earth Cryosphere, 3, 59-70.

[23] Anisimova, N.P. (1966) The Temperature of Bottom Sediments as an Indicator of Sublacustrine Talik Thickness In: Grave, N.A. and Nekrasov, I.A., Eds., Materials of VIII All-Union Inter-Ministerial Meeting on Geocryology, 3 (Regional Geocryology), Yakutskoe Knizhnoe Izdatelstvo, Yakutsk, 188-197.

[24] Are, F.E. (1974) Thermal Regime of Shallow Lakes of the Taiga Zone of Eastern Siberia (on the Example of Central Yakutia). In: Are, F.E., Ed., Lakes of the Permafrost Zone of Siberia, Nauka, Novosibirsk, 98-116.

[25] Tishin, M.I. (1978) Temperature Regime of the Water Mass of the Lake Syrdakh. In: 
Pavlov, A.V., Ed., Geophysical Studies in Siberia, Nauka, Novosibirsk, 58-66.

[26] Melnikov, V.P., Nesterov, A.N., Podenco, L.S., Reshetnikov, A.M. and Shalamov, V.V. (2011) Metastable States of Gas Hydrates at Pressures below the Equilibrium Pressure of the Ice-Hydrate-Gas. Earth Cryosphere, 15, 80-83.

[27] Istomin, V.A. and Yakushev, V.S. (1992) Gas Hydrates in Natural Conditions. Nedra, Moscow.

[28] Zelenina, L.I. and Fedkyshova, S.I. (2012) Forecasting and the Results of Climatic Changes in the Arctic Region. Arctic and the North, 5, 1-5.

[29] Alekseev, G.V., Ananicheva, M.D., Anisimov, O.A., Ashik, I.M., Bardin, M.Yu., Bogdanova, E.G., et al. (2014) Second Roshydromet Assessment Report on Climate Change and Its Consequences in Russian Federation. General Summary, Federal Service for Hydrometeorology and Environmental Monitoring (Roshydromet), Moscow.

[30] Bocharov, G.V., Gusev, G.S., Esikova, L.V. and Spektor, V.B. (1982) The Map of Recent Vertical Movements of the Yakutsk ASSR Territory. Geotectonics, 3, 60-64.

[31] Razumov, S.O., Spektor, V.B. and Grigoriev, M.N. (2014) Model of the Post-Cenozoic Evolution of the Cryolithozone of the Shelf of the Western Part of the Laptev Sea. Oceanology, 54, 679-693. https://doi.org/10.1134/S0001437014040092

[32] Walter, K.M., Zimov, S.A., Chanton, J.P., Verbyla, D. and Chapin III, F.S. (2006) Methane Bubbling from Siberian Thaw Lakes as a Positive Feedback to Climate Warming. Nature, 443, 71-75. https://doi.org/10.1038/nature05040

[33] Walter, K.M., Edwards, M.E., Grosse, G., Zimov, S.A. and Chapin III, F.S. (2007) Thermokarst Lakes as a Source of Atmospheric CH4 during the Last. Science, 318, 633-636. https://doi.org/10.1126/science.1142924

[34] Zimov, S.A., Schuur, E.A.G. and Chapin III, F.S. (2006) Permafrost and the Global Carbon Budget. Science, 312, 1612-1613. https://doi.org/10.1126/science.1128908

[35] Sergienko, V.I., Lobkovskii, L.I., Semiletov, I.P., Dudarev, O.V., Dmitrievskii, N.N., Shakhova, N.E., Romanovskii, N.N., Kosmach, D.A., Nikol'skii, D.N., Nikiforov, S.L., Salomatin, A.S., Ananev, R.A., Roslyakov, A.G., Salyuk, A.N., Karnaukh, V.V., Chernykh, D.B., Tumskoi, V.E., Yusupov, V.I., Kurilenko, A.V., Chuvilin, E.M. and Bukhanov, B.A. (2012) The Degradation of Submarine Permafrost and the Destruction of Hydrates on the Shelf of East Arctic Seas as a Potential Cause of the Methane Catastrophe: Some Results of Integrated Studies in 2011. Doklady Earth Sciences, 446, 1132-1137. https://doi.org/10.1134/S1028334X12080144

[36] Soloviev, V.A. (1987) Cryothermie and Natural Gas Hydrates in the Arctic Ocean. Sevmorgeo, Leningrad.

[37] Shakhova, N.E. and Semiletov, I.P. (2014) Methane in the Seas of the Eastern Arctic: Selected Results of the Study (1994-2014).

http://www.ras.ru/FStorage/download.aspx?id=0e8cedce-f45f-4645-ab67-8ce6e88e6 b66

[38] Romanovskii, N.N., Kholodov, A.L., Gavrilov, A.V., Tumskoy, V.E., Hubberten, H.-W. and Kassens, H. (1999) Ice-Bonded Permafrost Thickness in the Eastern Part of the Laptev Sea Shelf (Results of Computer Modeling). Earth Cryosphere, 3, $22-32$.

[39] Anisimov, O.A., Borzenkova, I.I., Lavrov, S.A. and Strel'chenko, Yu.G. (2012) The Current Dynamics of the Submarine Permafrost and Methane Emissions on the Shelf of the Eastern Arctic Seas. Ice and Snow, 52, 97-105.

[40] Malakhova, V.V. and Golubeva, E.N. (2016) Estimation of the Permafrost Stability 
on the East Arctic Shelf under the Extreme Climate Warming Scenario for the XXI Century. Ice and Snow, 56, 61-72. https://doi.org/10.15356/2076-6734-2016-1-61-72

[41] Frederick, J.M. and Buffett, B.A. (2014) Taliks in Relict Submarine Permafrost and Methane Hydrate Deposits: Pathways for Gas Escape under Present and Future Conditions. Journal of Geophysical Research: Earth Surface, 119, 106-122. https://doi.org/10.1002/2013JF002987

[42] Malakhova, V.V. (2016) Modeling of Submarine Taliks of the Laptev Sea Shelf. Proceedings of the 12 th International Conference Interexpo Geo-Siberia, Novosibirsk, 18-22 April 2016, Vol. 1, 120-124.

[43] Grosswald, M.G. (1999) Cataclysmic Megafloods in Eurasia and the Polar Ice Sheets. An Essay in Geomorphological Analysis of Continental Paleohydrological Systems. Scientific World, Moscow.

[44] Grosswald, M.G. (2009) Ice Sheets in the Russian North and North-East during the Last Great Chill. Data of Glaciological Studies, 106, 11-149.

[45] Winterfeld, M., Schirrmeister, L., Grigoriev, M.N., Kunitsky, V.V., Andreev, A., Murray, A. and Overduin, P.P. (2011) Coastal Permafrost Landscape Development since the Late Pleistocene in the Western Laptev Sea, Siberia. Boreas, 40, 697-713. https://doi.org/10.1111/j.1502-3885.2011.00203.x

[46] Grigoriev, M.N. (2006) Morphology and Dynamics of Transformation of Submarine Permafrost in the Coastal-Shelf Zone of the Laptev and East Siberian Seas. Nauka i Obrazovanie, No. 4, 104-109.

[47] Malakhova, V.V. and Golubeva, E.N. (2013) On Possible Methane Emissions from the East Arctic Seas. Atmospheric and Oceanic Optics, 26, 452-458.

[48] Anfilatova, E.A. (2008) A Review of Modern Foreign Data on the Problem of Occurrence of Gas Hydrates World Offshore. Neftegazovaya Geologiya. Teoriya I Praktika, 3, 1-15.

[49] Shakhova, N.E., Yusupov, V.A., Salyuk, A.N., Kosmach, D.A. and Semiletov, I.P. (2009) Anthropogenic Factor and Methane Emission on the East-Siberian Shelf. Doklady Earth Sciences, 429A, 1488-1491. https://doi.org/10.1134/S1028334X09090165

[50] Yurganov, L.N. and Leifer, A. (2016) Abnormal Concentrations of Atmospheric Methane over the Okhotsk Sea in Winter 2015/2016. Modern Problems of Remote Sensing of the Earth from Space, 13, 231-234. https://doi.org/10.21046/2070-7401-2016-13-3-231-234

[51] Grigoriev, M.N. (2017) Studies of Permafrost Degradation of the Seas of East Siberia (According to the Results of Expedition 2014-2016). Problems of the Arctic and Antarctic, No. 1, 89-96.

[52] Safronov, A.F., Shits, E.Yu., Grigor'ev, M.N. and Semenov, M.E. (2010) Formation of Gas Hydrate Deposits in the Siberian Arctic Shelf. Russian Geology and Geophysics, 51, 83-87. https://doi.org/10.1016/j.rgg.2009.12.006

[53] Paull, C.K., Ussler, W., Dallimore, S.R., Blasco, S.M., Lorenson, T.D., Melling, H., Medioli, B.E, Nixon, F.M. and McLaughlin, F.A. (2007) Origin of Pingo-Like Features on the Beaufort Sea Shelf and Their Possible Relationship to Decomposing Methane Gas Hydrates. Geophysical Research Letters, 34, 1-5. https://doi.org/10.1029/2006GL027977

[54] Judd, A.G., Hovland, M., Dimitrov, L.I., Garica, G.S. and Jukes, V. (2002) The Geological Methane Budget at Continental Margins and Its Influence on Climate Change. Geofluids, 2, 109-126. https://doi.org/10.1046/j.1468-8123.2002.00027.x

[55] Dyadin, Y.A. and Guschin, A.L. (1998) Gas Hydrates. Soros Educational Journal 
Chemistry, 3, 55-64.

[56] Zakharenko, V.S. (2011) Potential Ecological Risk Related to Gas-Hydrates Deposits within West Arctic Continental Margin. Environment Protection in Oil and Gas Complex, 4, 21-26.

[57] Gavrilova, M.K. (2007) Zoning of the Russian North. In: Filippov, V.V., Ed., Proceedings "Zoning of the Russian North", Publishing House of the Permafrost Institute, SB RAS, Yakutsk, 64-98.

[58] Duchkov, A.D, Sokolova, L.S., Ayunov, D.E. and Permyakov, M.E. (2009) Assessment of Potential of West Siberian Permafrost for the Carbon Dioxide Storage. Earth's Cryosphere, 13, 62-68.

[59] Kattsov, V.M. and Porfiryev, B.N. (2012) Climate Change in the Arctic: The Consequences for the Environment and the Economy. Arctic. Ecology and Economics, No. 2, 66-77.

[60] Kiselev, A.A. and Reshetnikov, A.I. (2013) Methane in the Russian Arctic: The Results of Observations and Calculations. Problems of the Arctic and Antarctic, No. 2, 5-15.

[61] Spector, V.B., Kerchengolts, B.M., Lifshitz, S.H. and Spector, V.V. (2007) A Carbonate-Methane System of Planetary Self-Regulation of Climate. Izvestiya RAN: Seriya Geographicheskaya, 6, 1-12.

[62] Petit, J.R., Jouzel, J., Raynaud, D., Barkov, N.I., Barnola, J.-M., Basile, I., Bender, M., Chappellaz, J., Davis, M., Delaygue, G., Delmotte, M., Kotlyakov, V.M., Legrand, M., Lipenkov, V.Y., Lorius, C., Pepin, L., Saltzman, E. and Stievenard, M. (1999) Climate and Atmospheric History of the Past 420,000 Years from the Vostok Ice Core, Antarctica. Nature, 399, 429-436. https://doi.org/10.1038/20859

[63] http://sweet211.ru/kolichestvo-klimaticheskih-kataklizmov-rezko-vozroslo.html

[64] Mann, M.E., Rahmstorf, S., Kornhuber, K., Steinman, B.A., Miller, S.K. and Coumou, D. (2017) Influence of Anthropogenic Climate Change on Planetary Wave Resonance and Extreme Weather Events. Scientific Reports, 7, Article No. 45242. http://www.nature.com/articles/srep45242

[65] http://tass.ru/spec/climate

[66] Yudovich, Y.E. (2009) Geochemical Davos Fashion-2009. Bulletin of the Institute of Geology, 7, 25-33.

[67] Adushkin, V.V., Soloviev, S.P. and Turuntaev, S.B. (2001) The Ratio of Anthropogenic and Natural Components in the Flow of Gases into the Atmosphere. In: Dobretsov, N.L. and Kovalenko, V.I., Eds., Global Changes of Environment 2001, SB RAS, GEO, Novosibirsk, 249-264.

[68] Nauta, A.L., Heijmans, M.P.D., Blok, D., Limpens, J., Elberling, B., Gallagher, A., Li B., Petrov, R.E., Maximov, T.C., Huissteden, J. and Berendse, F. (2014) Permafrost Collapse after Shrub Removal Shifts Tundra Ecosystem to a Methane Source. Nature Climate Change. http://www.nature.com/natureclimatechange

[69] Knoblauch, Ch., Beer, Ch., Liebner, S., Grigoriev, M.N. and Pfeiffer, E.M. (2018) Methane Production as Key to the Greenhouse Gas Budget of Thawing Permafrost. Nature Climate Change. http://www.nature.com/natureclimatechange 